\title{
Topical antiinflammatory activity and chemical composition of the epicuticular wax from the leaves of Eugenia beaurepaireana (Myrtaceae)
}

\author{
Michele Debiasi Alberton Magina ${ }^{1}$, Evelise Fernades Pietrovski², Franciane Gomig², Daniel de \\ Barcellos Falkenberg ${ }^{3}$, Daniela Almeida Cabrini², Michel Fleith Otuki², Moacir Geraldo Pizzollati ${ }^{4}$, \\ Inês Maria Costa Brighente ${ }^{4^{*}}$
}

\begin{abstract}
${ }^{1}$ Department of Pharmacy, Regional University of Blumenau, ${ }^{2}$ Department of Pharmacology, Federal University of Paraná, ${ }^{3}$ Department of Botany, Federal University of Santa Catarina, ${ }^{4}$ Laboratory of Chemistry of Natural Products, Department of Chemistry, Federal University of Santa Catarina
\end{abstract}

\begin{abstract}
In order to verify the topical antiinflammatory effect of epicuticular wax from leaves of Eugenia beaurepaireana, it was tested in mice croton oil-induced inflammation. Our findings show that topical application of Eugenia beaurepaireana epicuticular wax was significantly active in inhibiting both oedema (Inhibitory dose $50 \%\left(\mathrm{ID}_{50}\right)=0.31(0.26-0.39) \mathrm{mg}^{-e^{-1}}{ }^{-1}$, inhibition $\left.=79 \pm 6 \%\right)$ and tissue myeloperoxidase activity (indicative of polymorphonuclear leukocytes influx) $\left(\mathrm{ID}_{50}=0.34(0.20-0.41)\right.$ mg.ear ${ }^{-1}$, inhibition $=77 \pm 4 \%$ ) in mice ear treated with croton oil. Two main compounds were detected on epicuticular wax of E. beaurepaireana. These compounds were identified as $\alpha$-and $\beta$-amyrin by flame ionization detection (GC-FID) and spectroscopic methods (IR, NMR ${ }^{1} \mathrm{H}$ and ${ }^{13} \mathrm{C}$ ). In conclusion, the results indicate a topical antiinflammatory activity for the Eugenia specie studied and, that, at least in part, $\alpha$ - and $\beta$-amyrin are responsible for this activity.
\end{abstract}

Uniterms: Eugenia beaurepaireana/pharmacognosy. $\alpha$-amyrin. $\beta$-amyrin. Epicuticular wax/ antiinflammatory activity. Ear oedema/experimental study.

A atividade antiinflamatória tópica da cera epicuticular das folhas de Eugenia beaurepaireana foi avaliada pelo modelo do edema de orelha induzido pelo óleo de cróton em camundongos. Os resultados do estudo mostram que a aplicação tópica da cera epicuticular de Eugenia beaurepaireana inibiu significativamente a formação do edema (Dose inibitória $50 \%\left(\mathrm{DI}_{50}\right)=0,31(0,26-0,39) \mathrm{mg}_{\text {. orelha }}{ }^{-1}$, inibição $=79 \pm 6 \%$ ) e a atividade da mieloperoxidase tissular (indicativo do influxo de leucócitos polimorfonucleares) $\left(\mathrm{DI}_{50}\right.$ $=0,34(0,20-0,41)$ mg.orelha ${ }^{-1}$, inibição $\left.=77 \pm 4 \%\right)$ em camundongos tratados com o óleo de cróton. Dois compostos majoritários foram detectados e isolados da cera epicuticular de E. beaurepaireana. Estes compostos foram identificados como os triterpenos $\alpha$-amirina e $\beta$-amirina, através de técnicas cromatográficas (CG-FID) e espectroscópicas (IV, RMN ${ }^{1} \mathrm{He} \mathrm{e}^{13} \mathrm{C}$ ). Em conclusão, os resultados indicam que a espécie $E$. beaurepaireana apresenta um efeito antiinflamatório tópico relevante, sendo os compostos $\alpha$-amirina e $\beta$-amirina responsáveis, pelo menos em parte, por esta atividade.

Unitermos: Eugenia beaurepaireana/farmacognosia. $\alpha$-amirina. $\beta$-amirina. Cera epicuticular/atividade antiinflamatória. Edema de orelha/estudo experimental.

\section{INTRODUCTION}

Epicuticular waxes are complex mixtures of long

\footnotetext{
*Correspondence: I. M. C. Brighente. Laboratório de Química de Produtos Naturais, Departamento de Química, Universidade Federal de Santa Catarina, Campus Trindade - 88040-900 - Florianópolis - SC, Brasil. E-mail: ines@qmc.ufsc.br
}

chain aliphatic and cyclic components, including hydrocarbons, primary and secondary alcohols, aldehydes, ketones, esters, fatty acids, triterpenoids and flavonoids that cover the external side of the leaf epidermis of all higher plants (Alcerito et al., 2002; Furlan et al., 2006; Medina et al., 2006). The physical and chemical properties of epicuticular wax determine functions vital for plant life. It restricts 
non-stomatal water loss, protects plants against ultraviolet radiation and reduces water retention on the surface of the plant thus minimizing deposition of dust, pollen and air pollutants. In addition, surface wax is believed to play important roles in plant defense against bacterial and fungal pathogens and has been shown to participate in a variety of plant-insect interactions (Kunst, Samuels, 2003).

The family Myrtaceae consists of around 129 genera and 4620 species. One important genera of this family is Eugenia, which is one of the larger genera with around 500 species. Several species of Eugenia have been reported for uses in folk medicine (Lee et al., 1997; Revilla, 2002). Eugenia beaurepaireana (Kiaerskou) Legrand (Myrtaceae) is a tree popularly called "ingabaú" or "guamirim-ferro". The use of $E$. beaurepaireana in South of America is recommended for the treatment of inflammatory and ulcerative diseases and used as astringent (Revilla, 2002). There have been no previous reports of isolated compounds and biological activities of this species. One study on the essential oils of this plant has demonstrated that bicyclogermacrene, $\Delta$-cadinene, $\tau$-cadinol and $\beta$-caryophyllene are the major compounds in E. beaurepaireana essential oil (Apel et al., 2004).

Tissue injury triggers a homeostatic response in which various cells populations like as keratinocytes, neutrophils and mast cells release proinflammatory mediators such as cytokines, prostaglandins, and leukotrienes that are coordinated to achieve repair, defined as the reestablishment of vital functions (Puignero, Queralt, 1997; Kim, Wong, Coulombe, 2006). However, chronic inflammatory response that is characteristic of many skin diseases as psoriasis (Lebwohl, 2003). These diseases can be treated either topically or systemically with glucocorticoids, immunosuppressors, and more recently, with monoclonal antibodies and recombinant cytokines (Nickoloff, Stevens, 2006).

However, these therapeutic alternatives are usually aggressive and not effective in all cases (Gottlieb, 2005). Thus, many studies are being developed with the purpose of finding better treatment options with higher efficacy and fewer side effects. One of the strategies used for the medicine development is the use of medicinal plants (Calixto, Otuki, Santos, 2003).

In order to verify the topical antiinflammatory effect of $E$. beaurepaireana, its epicuticular wax from leaves was tested in mice skin inflammation model.

\section{MATERIAL AND METHODS}

\section{Material}

Croton oil, dexamethasone, hexadecyltrimethylammonium bromide, tetramethylbenzidine hydrogen peroxide, formaldehyde, tween 80 , phosphate-buffered saline eosin, hematoxylin were from Sigma, St. Louis, USA. Sodium acetate, dimethylformamide, acetone, formaldehyde, and absolute ethanol were from Merck, Darmstadt, Germany.

\section{Wax extraction}

Leaves of $E$. beaurepaireana were collected in the city of Santo Amaro da Imperatriz (SC), in September 2004. Voucher specimens were identified by Prof. Dr. Daniel de Barcellos Falkenberg (Botany Department, UFSC) and deposited at the Universidade Federal de Santa Catarina Herbarium at number FLOR-34674. Epicuticular wax was extracted from fresh and healthy leaves by wash in hexane for $5 \mathrm{~min}$. Wax extract was filtered and evaporated to dryness at rotary evaporator under $40^{\circ} \mathrm{C}$.

\section{Chemical analysis}

Chemical composition of extracted epicuticular wax was analyzed by capillary gas chromatography flame ionization detection (GC-FID) using GC Shimadzu 14-B equipment with DB- 1 column ( $30 \mathrm{~m}$ x $0.25 \mathrm{~mm}$; film thickness $0.25 \mu \mathrm{m}$ ). Hydrogen acted as carrier gas. The chromatographic conditions used were temperature program $60{ }^{\circ} \mathrm{C}$ to $300{ }^{\circ} \mathrm{C}$, with increasing of $10{ }^{\circ} \mathrm{C} \cdot \mathrm{min}^{-1}$. The temperatures of injector and detector were $300^{\circ} \mathrm{C}$ and $290{ }^{\circ} \mathrm{C}$, respectively.

Identification of wax compounds was done by GC retention index, by co-injection with standards of $\alpha$-amyrin (1) and $\beta$-amyrin (2), and spectroscopic methods (IR, NMR ${ }^{1} \mathrm{H}$ and ${ }^{13} \mathrm{C}$ ), in comparison with published data (Mahato, Kundu, 1994).

\section{Animals}

Male Swiss mice $(25-35 \mathrm{~g})$ housed at $22 \pm 2{ }^{\circ} \mathrm{C}$ and with access to food and water ad libitum, were used in these experiments that were performed during the light phase of the cycle. The animals were allowed to adapt to the laboratory for at least $1 \mathrm{~h}$ before testing and were used only once. Experiments reported in this study were performed after approval of the protocol $n^{\circ} 127$ by the Institutional Ethics of UFPR University and were carried out in accordance with the "Principles of laboratory animal care" from NIH publication 85-23.

\section{Ear oedema measurement}

Oedema was expressed as the increase in ear thick- 
ness due to the inflammatory challenge. Ear thickness was measured before and after induction of the inflammatory response by using a digital micrometer (Great, MT-045B). The micrometer was applied near the tip of the ear just distal to the cartilaginous ridges and the thickness was recorded in $\mu \mathrm{m}$. To minimize variation due to technique, a single investigator performed the measurements throughout any one experiment. Epicuticular wax of $E$. beaurepaireana was topically applied in $20 \mu \mathrm{L}$ acetone (Otuki et al., 2005).

\section{Croton oil-induced dermatitis}

Oedema was induced on the right ear by topical application of $0.1 \mathrm{mg}$.ear ${ }^{-1}$ of croton oil dissolved in 20 $\mu l$ of acetone. Epicuticular wax of $E$. beaurepaireana and dexamethasone (used as a positive control) was topically applied simultaneously with croton oil. The thickness of the ears was measured before and $6 \mathrm{~h}$ after the induction of inflammation (Swingle, Reiter, Schwartzmiller, 1981; Tragni et al., 1985).

\section{Tissue myeloperoxidase activity assay}

The activity of tissue myeloperoxidase was assessed $24 \mathrm{~h}$ after croton oil application to the mouse ear according to the technique reported by Suzuki et al. (1983) and modified by De Young et al. (1989). A biopsy (6 mm ear tissue punch) was placed in $0.75 \mathrm{~mL}$ of $80 \mathrm{mM}$ phosphatebuffered saline (PBS) pH 5.4, containing $0.5 \%$ hexadecyltrimethylammonium bromide, then homogenized ( $45 \mathrm{~s}$ at $0{ }^{\circ} \mathrm{C}$ ) in a motor-driven homogenizer. The homogenate was decanted into a microfuge tube, and the vessel was washed with a second $0.75 \mathrm{~mL}$ aliquot of hexadecyltrimethylammonium bromide in buffer. The wash was added to the tube and the $1.5 \mathrm{~mL}$ sample was centrifuged at 12,000 $\mathrm{x}$ g at $4{ }^{\circ} \mathrm{C}$ for $15 \mathrm{~min}$. Triplicate $30 \mu \mathrm{L}$ samples of the

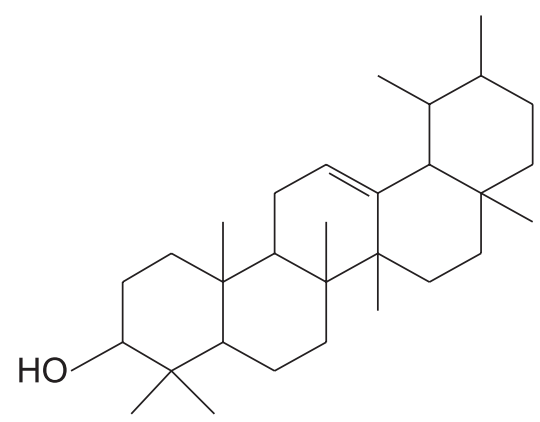

(1) resulting supernatant were added to 96 -well plates. For assay, $200 \mu \mathrm{L}$ of a mixture containing $100 \mu \mathrm{L}$ of $0.08 \mathrm{M}$ PBS pH 5.4, $85 \mu \mathrm{L}$ of $0.22 \mathrm{M}$ PBS pH 5.4, and $15 \mu \mathrm{L}$ of $0.017 \%$ hydrogen peroxide were added to the wells. The reaction was started with addition of $20 \mu \mathrm{L}$ of $18.4 \mathrm{mM}$ tetramethylbenzidine $\mathrm{HCl}$ in dimethylformamide. Plates were incubated at $37{ }^{\circ} \mathrm{C}$ for $3 \mathrm{~min}$ and then placed on ice where the reaction was stopped by addition of $30 \mu \mathrm{L}$ of $1.46 \mathrm{M}$ sodium acetate, pH 3.0. Enzyme activity was determined colorimetrically using a plate reader (EL808 - BioTech Instruments, INC) set to measure absorbance at $630 \mathrm{~nm}$ and expressed as $\mathrm{mOD} / \mathrm{mg}$ tissue.

\section{Statistical analysis}

The results are presented as means \pm S.E.M (standard error of mean), except the $\mathrm{ID}_{50}$ values (i.e., the dose of epicuticular wax of $E$. beaurepaireana reducing the inflammatory response by $50 \%$ relative to the control value), which are reported as geometric means accompanied by their respective $95 \%$ confidence limits. Data were subjected to analysis of variance (ANOVA) or t-test and complemented by Dunnett's post hoc test. $\mathrm{P}<0.05$ was considered as indicative of significance. The $\mathrm{ID}_{50}$ values were determined by linear regression from individual experiments using Graphpad Software (California, USA).

\section{RESULTS AND DISCUSSION}

Two main compounds were detected on epicuticular wax of $E$. beaurepaireana. They were identified as $\alpha$-and $\beta$-amyrin (Figure 1) by GC relative retention index with available standards and co-injection with authentic standards. The identification was confirmed by NMR and the spectral data of these isolated compounds stayed in agreement with literature (Mahato, Kundu, 1994; Park et al., 2004).

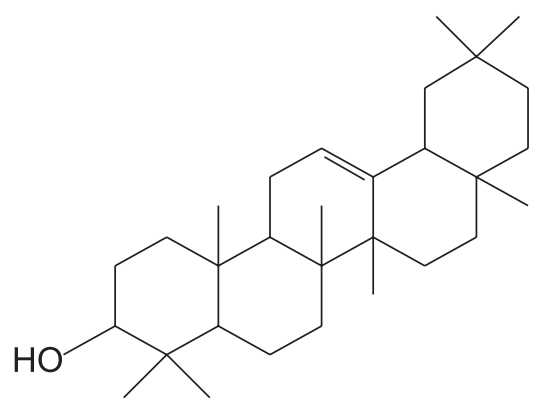

(2)

FIGURE 1 - Structures of $\alpha$ - (1) and $\beta$ - amyrin (2). 

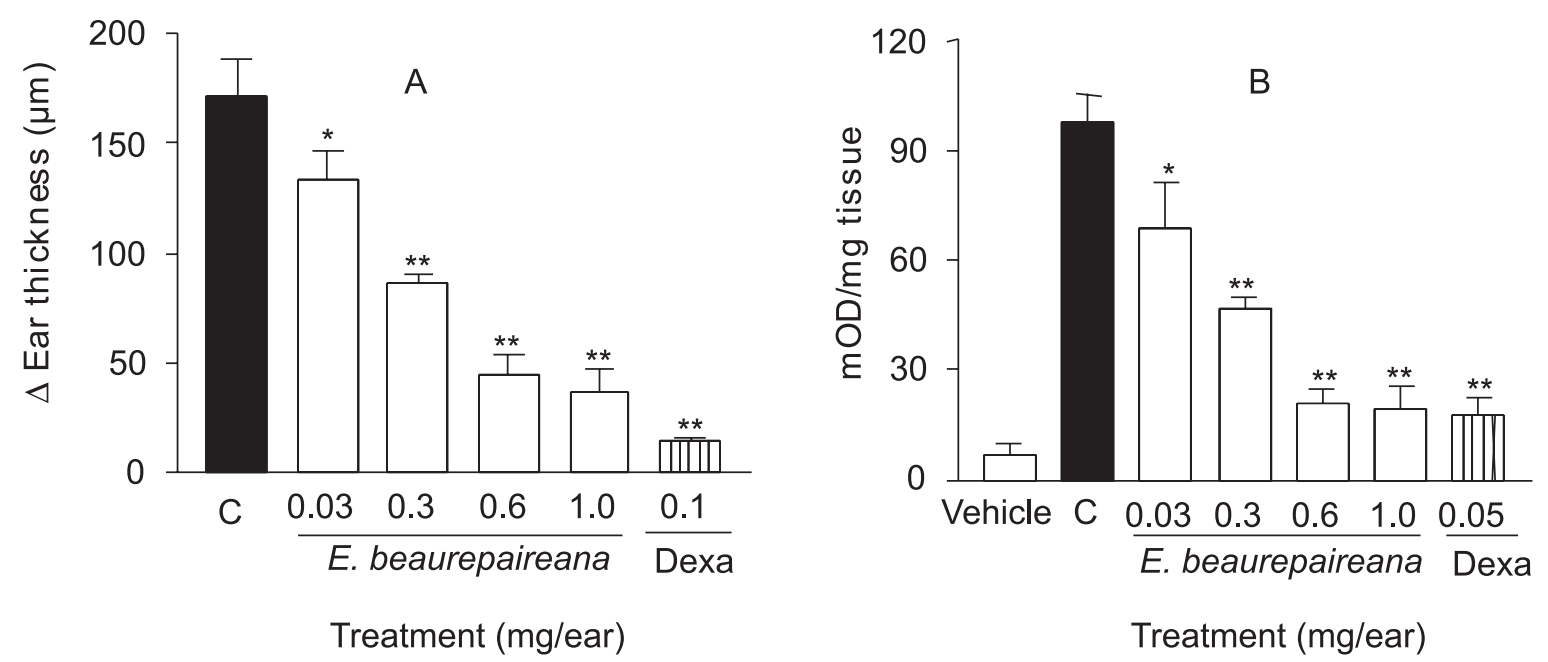

FIGURE 2 - Effect of Eugenia beaurepaireana and dexamethasone (Dexa) administered topically on (A) croton oil-induced ear edema and (B) myeloperoxidase activity in supernatants of homogenates from croton oil -treated ears. $\mathrm{C}=\mathrm{control}$; $\mathrm{mOD}=\mathrm{optical}$ density $\left(10^{-3}\right)$. Ear edema and myeloperoxidase activities were measured at 6 and $24 \mathrm{~h}$ after croton oil treatment, respectively. Each point represents the mean \pm S.E.M. for $6-8$ animals. The asterisks denote the significance levels when compared with control groups. Significantly different from controls, $* \mathrm{P}<0.05$ and $* * \mathrm{P}<0.01$.

The relative apparent percentage of each compound was determined by area of the peak, $\alpha$ - amyrin $(61.92 \%)$ showed to be more abundant than $\beta$-amyrin $(27.66 \%)$.

Triterpenes derivatives of ursane, such as ursolic acid (Srivasta, Shaw, Kulshreshtha, 1995) and oleanane structure, such 3-cis- $p$-coumaroyloxy-2- $\alpha$-oleanolic acid, were previously identified of Eugenia genus (Gu et al., $2001)$. However, this is a first study showing the presence of $\alpha$ - and $\beta$ - amyrin in E. beaurepaireana.

Topical application of croton oil has been used to screen for topically applied antiinflammatory steroids and nonsteroid agents and promotes events of inflammatory processes such as oedema, cell infiltration and proliferation, with the production of arachidonic acid metabolites, cytokines, and other proinflammatory mediators (Otuki et al., 2005).

As shown in Figure 2, the topical application of the epicuticular wax from the leaves of $E$. beaurepaireana was capable to prevent two important events of inflammation, namely oedema (Figure 2A) and the increase of cell migration (Figure 2B) caused by topical administration of croton oil in mice. The estimated $\mathrm{ID}_{50}$ values from the oedema and myeloperoxidase activity (indicative of polymorphonuclear leukocytes influx) were $0.31(0.26-0.39)$ and 0.34 (0.20-0.41) mg.ear ${ }^{-1}$, with inhibition of $79 \pm 6$ and $77 \pm$ $4 \%$, respectively. Dexamethasone, the reference drug, also cause a significant inhibition of both parameters, $81 \pm 3$ and $79 \pm 4 \%$, for oedema and myeloperoxidase activity, respectively (Figure 2B). The above reported actions are interesting because infection or injury of the tissue leads to an influx of neutrophils from blood and its accumulation plays a critical role in cutaneous inflammatory diseases such as dermatitis (Schaerli et al., 2004).

The antiinflammatory activity of E. beaurepaireana is explained, at least in part, by the presence of pentacyclic triterpenes $\alpha$ - and $\beta$-amyrin. This fact is supported by the antiinflammatory activity of $\alpha$ - and $\beta$-amyrin demonstrated in literature (Otuki et al., 2005). These works prove the efficacy of the topical application of $\alpha$ - and $\beta$-amyrin in models of skin inflammation induce by croton oil and TPA (12-O-tetradecanoylphorbolacetate) (Della Loggia et al., 1994; Recio et al., 1995; Akihisa et al., 1996; Otuki et al., 2005). Furthermore, Otuki and collaborators (2005) also demonstrated that the topical application of $\alpha$-amyrin is capable of reducing skin levels of IL-1 $\beta$, an important cytokine involved in skin inflammation. Thus, the present study demonstrates that the wax obtained from leaves of $E$. beaurepaireana possesses a topical antiinflammatory activity in mice, and this could be a source of the biologically active compounds and an alternative to search of a new medicine for the treatment of skin diseases.

\section{CONCLUSIONS}

The results show that topical application of Eugenia beaurepaireana epicuticular wax was significantly active in inhibiting both oedema and tissue myeloperoxidase activity in mice ear treated with croton oil. The results provide useful pharmacological information related to 
antiinflammatory activity of this species, and suggests the possibility of the usage of this plant against different pathologies related to topical inflammatory process.

\section{ACKNOWLEDGEMENTS}

This study was supported by grant from Conselho Nacional de Desenvolvimento Científico e Tecnológico (CNPq). Evelise F. Pietrovski is a PhD student in pharmacology and thanks CAPES for fellowship support. Michel F. Otuki receives a post-doctoral fellowship from UFPR/ CAPES/PRODOC.

\section{REFERENCES}

AKIHISA, T.; YASUKAWA, K.; OINUMA, H.; KASAHARA, Y.; YAMANOUCHI, S.; TAKIDO, M.; KUMAKI, K.; TAMURA, T. Triterpene alcohols from the flowers of compositae and their antiinflammatory effects. Phytochemistry, v.43, p.1255-1260, 1996.

ALCERITO, T.; BARBO, F.E.; NEGRI, G.; SANTOS, D.Y.A.C.; MEDA, C.I.; YOUNG, M.C.M.; CHÁVEZ, D.; BLATT, C.T.T. Foliar epicuticular wax of Arrabidaea brachypoda: flavonoids and antifungal activity. Biochem. Syst. Ecol., v.30, p.677-683, 2002.

APEL, M.A.; SOBRAL, M.; SCHAPOVAL, E.E.S.; HENRIQUES, A.T. Chemical composition of the essential oils of Eugenia beaurepaireana and Eugenia pyriformis: section dichotomae. J. Essent. Oil Res., v.16, p.191-192, 2004.

CALIXTO, J.B.; OTUKI, M.F.; SANTOS, A.R.Antiinflammatory compounds of plant origin. Part I. Action on arachidonic acid pathway, nitric oxide and nuclear factor kappa B (NFkappaB). Planta Med., v.69, p.973-983, 2003.

DE YOUNG, L.M.; KHEIFETS, J.B.; BALLARON, S.J.; YOUNG, J.M. Edema and cell infiltration in the phorbol ester-treated mouse ear are temporally separated and can be differentially modulated by pharmacologic agents. Agents Actions, v.26, p.335-341, 1989.

DELLA LOGGIA, R.; TUBAZO, A.; SOSA, S.; BECKER, H.; SAAR, S.; ISAAC, O. The role of triterpenoids in the topical antiinflammatory activity of Calendula officinalis flowers. Planta Med., v.60, p.516-520, 1994.
FURLAN, C.M.; SANTOS, D.Y.A.C.; SALATINO, A.; DOMINGOS, M. $n$-Alkane distribution of leaves of Psidium guajava exposed to industrial air pollutants. Environ. Exp. Botany, v.58, p.100-105, 2006.

GOTTLIEB, A.B. Therapeutic options in the treatment of psoriasis and atopic dermatitis. J. Am. Acad. Dermatol., v.53, p.3-16, 2005.

GU, J.; PARK, E.J.; LUYENGI, L.; HAWTHORNE, M.F.; MEHTA, R.G.; FARNSWORTH, N.R.; PEZZUTO, J.M.; KINGHORN, A.D. Constituents of Eugenia sandwicensis with potential cancer chemopreventive activity. Phytochemistry, v.58, p.121-127, 2001.

KIM, S.; WONG, P.; COULOMBE, P.A. A keratin cytoskeletal protein regulates protein synthesis and epithelial cell growth. Nature, v.441, p.362-365, 2006.

KUNST, L.; SAMUELS, A.L. Biosynthesis and secretion of plant cuticular wax. Prog. Lipid Res., v.42, p.51-80, 2003.

LEBWOHL, M. Psoriasis. Lancet, v.361, p.1197-1204, 2003.

LEE, M.; NISHIMOTO, S.; YANG, L.; YEN, A.Y.; HATANO, T.; YOSHIDA, T.; OKUDA, T. Two macrocyclic hydrolisable tannin dimers from Eugenia uniflora. Phytochemistry, v.44, p.1343-1349, 1997.

MAHATO, S.B.; KUNDU, A.P. ${ }^{13}$ C NMR Spectra of pentacyclic triterpenoids-a compilation and some salient features. Phytochemistry, v.37, p.1517-1575, 1994.

MEDINA, E.; AGUIAR, G.; GÓMEZ, M.; ARANDA, J.; MEDINA, J.D.; WINTER, K. Taxonomic significance of the epicuticular wax composition in species of the genus Clusia from Panama. Biochem. Syst. Ecol., v.34, p.319326, 2006.

NICKOLOFF, B.J.; STEVENS, S.R. What have we learned in dermatology from the biologic therapies? J. Am. Acad. Dermatol., v.54, p.143-151, 2006.

OTUKI, M.F.; VIEIRA-LIMA, F.; MALHEIROS, A.; YUNES, R.A.; CALIXTO, J.B. Topical antiinflammatory effects of the ether extract from Protium kleinii and $\alpha$-amyrin pentacyclic triterpene. Eur. J. Pharmacol., v.507, p.253259, 2005. 
PARK, B.; MIN, B.; OH, S.; KIM, J.; KIM, T.; KIM, D.; BAE, K.; LEE, H. Isolation and anticomplement activity of compounds from Dendropanax morbifera. $J$. Ethnopharmacol., v.90, p.403-408, 2004.

PUIGNERO, V.; QUERALT, J. Effect of topically applied cyclooxygenase-2-selective inhibitors on arachidonic acid- and tetradecanoylphorbol acetate-induced dermal inflammation in the mouse. Inflammation, v.21, p.431-442, 1997.

RECIO, M.C.; GINER, R.M.; MANEZ, S.; RIOS, J.L. Structural requirements for the antiinflammatory activity of natural triterpenoids. Planta Med., v.61, p.182-185, 1995.

REVILLA, J. Plantas úteis da bacia amazônica. Rio de Janeiro: Inpa, 2002. p.44.

SCHAERLI, P.; BRITSCHGI, M.; KELLER, M.; STEINER, U.C.; STEINMANN, L.S.; MOSER, B.; PICHLER, W.J. Characterization of human T cells that regulate neutrophilic skin inflammation. J. Immunol., v.173, p.2151-2158, 2004.
SRIVASTA, R.; SHAW, A.K.; KULSHRESHTHA, D.K. Triterpenoids and chalcone of Syzygium samarangense. Phytochemistry, v. 38, p.687-689, 1995.

SUZUKI, K.; OTA, H.; SASAGAWA, S.; SAKATANI, T.; FUJIKURA, T. Assay method for myeloperoxidase in human polymorphonuclear leukocytes. Anal. Biochem., v.132, p.345-352, 1983.

SWINGLE, K.F.; REITER, M.J.; SCHWARTZMILLER, D.H. Comparison of croton oil and cantharidin induced inflammations of the mouse ear and their modification by topically applied drugs. Arch. Int. Pharmacodyn. Ther. v.254, p.168-176, 1981.

TRAGNI, E.; TUBARO, A.; MELIS, S.; GALLI, C.L. Evidence from two classic irritation tests for an antiinflammatory action of a natural extract, Echinacina B. Food Chem. Toxicol., v.23, p.317-319, 1985.

Recebido para publicação em 21 de maio de 2008. Aceito para publicação em 18 de agosto de 2008. 